\title{
KOAH Olgularında Dinamik Hiperinflasyonun Negatif Ekspiratuar Basınç Yöntemi İle Değerlendirilmesi
}

\author{
Hande İkitimur¹, Gülfidan Uzan² \\ 1 Biruni Üniversitesi Tıp Fakültesi, Göğüs Hastalıkları Anabilim Dalı, İstanbul, Türkiye \\ ${ }^{2}$ Haseki Eğitim ve Araştırma Hastanesi, Göğüs Hastalıkları Anabilim Dalı, İstanbul, Türkiye
}

\section{Abstract}

Amaç: KOAH, tam olarak reversibl olmayan progresif hava akımı kısıtılığı ile karakterize bir hastalıktır. Ekspiratuar akım kısıtlaması (EAK), KOAH'ta dinamik hiperinflasyon (DH) ve artmış solunum yükünün en sık nedenidir. Çalışmamızda KOAH’lı olgularda DH'nun incelenmesinde Negatif Ekspiratuar Basınç (NEP) ile bașta Inspiratuar Kapasite (IC) olmak üzere tüm solunum fonksiyon testleri arasındaki ilișki araștırılmıștır.

Yöntemler: Ortalama FEV1 değeri \% 38,9 \pm 12,7 olan 34 KOAH'lı olgu ile 15 sağlıklı olgu çalışmaya dahil edilmiştir. KOAH'lı olgulara solunum fonksiyon testleri ve NEP uygulanmıștır.

Bulgular: KOAH'lı olguların 16 (\% 47,1)' sında NEP ile EAK pozitif saptanmıştır. NEP ile EAK pozitif ve negatif saptanan grupların solunum fonksiyonları karşılaştırıldığında yalnızca FEV1 ve FEF25-75 gibi obstrüksiyon parametreleri ile anlamlı fark saptanmış, akciğer volümleri ve difüzyon testi ile bir fark saptanmamıștır. Oysa IC ile FVC ( $\mathrm{mL}$ ve \% predikte), FEV1 (\% predikte) değerleri arasında ve akciğer volümleri ( $\mathrm{mL}$ ve \% predikte) ile FRC (mL) arasında istatistiksel olarak anlamlı korelasyon saptanmıștır $(p<0,05)$. IC ile akım kısıtlamasının varlığı arasında ise negatif fakat istatistiksel olarak anlamlı olmayan bir korelasyon bulunmuştur $(p>0,05)$.

Sonuç: Sonuç olarak; çalıșmamızda KOAH'lı olgularda NEP uygulamasının DH hakkında ek bilgi sağlamadığını, IC'nin, DH'nun en iyi prediktörü olduğunu düşünmekteyiz.

Anahtar Kelimeler: KOAH, İnspiratuar Kapasite, Negatif Ekspiratuar Basınç

Kısa Bașlık:

\section{GíRİ̧}

Kronik obstrüktif akciğer hastalığı (KOAH), tam olarak reversibl olmayan progresif hava akımı kısıtlılığı ile karakterize, değişik zararlı partikül ve gazlara bağlı olarak gelișen inflamatuar bir hastalıktır. KOAH’taki hava akımı kısıtlılığı küçük hava yolu hastalığı ve parenkim destrüksiyonu sonucu gelișir. Kronik inflamasyon remodelinge ve küçük hava yollarında daralmaya yol açarken, parenkim hasarı sonucu elastik geri çekilme gücünün azalması ekspirasyon süresince hava yollarının açıklığının sürdürülmesini güçleștirir (1).

KOAH'lı olgularda spontan solunum sırasında azalmış ekspiratuar akımlara bağlı olarak akciğerin boşalmasındaki gecikme, bir sonraki inspirasyon öncesinde akciğerlerin pasif olarak fonksiyonel rezidüel kapasite (FRC) düzeyine gelișini engeller. Bunun sonucunda ekspiryum sonu akciğer volümü FRC düzeyini aşar. KOAH'ta azalmış elastik geri çekilme gücü ve hava yolu rezistansı nedeniyle akciğer volümleri artar. Böylece ekspiryum sonunda FRC'nin daha üst düzeyinde yeni bir denge olușur. Bu olay dinamik hiperinflasyon (DH) olarak adlandırılır (2).

KOAH'da, solunum fonksiyon testleri (SFT) hastalığın tanısında, şiddetinin belirlenmesinde, hastalık seyrinin ve prognozunun değerlendirilmesinde ve tedaviye yanıtı izlemede en sık kullanılan laboratuar yöntemidir (3). KOAH tanısının kesinleștirilebilmesi için spirometrik inceleme yapılması zorunludur. KOAH'ta solunum yollarında dinamik kollaps varlığını göstermede 
inspirasyon kapasite (IC)'nin yol gösterici olduğu bildirilmiștir (3). IC, sakin solunum sırasında ekspiryum tamamlandıktan sonra derin bir inspiryumla akciğerlere alınabilen gaz hacmidir. Soluk volümü ve inspiratuar rezerv volümü içerir. Vital kapasitenin yaklaşık \%75'ini oluşturur. Son yıllarda yapılan çalıșmalarda, KOAH'ta solunum yollarında dinamik hiperinflasyonun varlığını göstermede IC'nin önemli bir parametre olduğu gösterilmiștir $(4,5)$.

KOAH'ta spirometrede saptanabilen en önemli değişiklikler ekspiratuar akımlardaki kısıllanmadır. DH'nun en önemli nedeni olan ekspiratuar akımı kısıtlılığı (EAK)'nı göstermenin en basit yollarından biri de negatif ekspiratuar basınç (NEB) uygulamasıdır. NEB tekniği, genellikle $-5 \mathrm{cmH} 20$ civarında negatif bir basıncı, tidal ekspirasyon esnasında ağız içine uygulamak ve ortaya çıkan akım-volüm (A-V) halkasını, önceden yapıımış kontrol ekspirasyon A-V halkası ile kıyaslamaktan olușmaktadır. NEB tekniği $\mathrm{KOAH}$ olgularında; mekanik ventilatöre bağlı iken, egzersiz durumunda, dispneik ve ortopneik durumda, bronkodilatasyon önce ve sonrasında ve değişik pozisyonlarda uygulanabilmektedir. KOAH gibi hava akımı kısıtlamasının var olduğu durumlarda maksimal ekspiratuar akımlar istirahatte bile elde edilebilir. KOAH'lı olgularda özellikle egzersiz sırasında ekspiryum sonunda akciğerlerde kalan gaz volümünün arttığı görülür. Bu durumun sonucu olarak ekspiratuar rezerv volüm artar, inspiratuar rezerv volüm azalır, IC ise azalır. Bunun nedeni egzersiz sırasında artan dinamik kollaps nedeniyle periferik solunum yollarının kollabe olması ve ekspiratuar rezerv volümün artmasıdır. KOAH olgularında efor sırasında tidal volümdeki artış IC değerine kadar erişebilmektedir. Ayrıca bu hastalarda tidal volüm sırasında oluşan akım hızları maksimal ekspirasyon halkasındaki akım hızlarına ulaşabilmektedir. Bunun akımvolüm halkasındaki yansıması ise, efor sırasında çizdirilen tidal volüm eğrisinin, maksimal ekspirasyon eğrisi ile çakışmasıdır yani EAK'nın pozitif olmasıdır. KOAH olgularında EAK'nın varlığı; dinamik hiperinflasyona, solunum işinde artışa, inspiratuar kas fonksiyonunun bozulmasına ve progresif dispneye neden olmaktadır $(4,5,6,7)$.

Çalışmamızda, KOAH olgularında DH'nun incelenmesinde NEB ile solunum fonksiyon testleri ve akciğer volümleri arasındaki ilișkilerin incelenmesi hedeflenmiștir.

\section{YÖNTEMLER}

Çalışmamıza KOAH Polikliniğimizde izlenmekte olan Evre II ve III (1) düzeyinde otuz dört stabil dönemde KOAH'lı hasta ile sigara anamnezi ve herhangi bir solunum sistemi hastalığı olmayan on beș sağlıklı olgu dahil edilmiștir. Çalıșmaya katılan
KOAH'lı olgular; inhaler uzun etkili beta-mimetik, antikolinerjik, inhaler steroid ve oral teofilin ile lüzum halinde inhaler kısa etkili beta mimetik kullanmaktaydı. Stabil dönem; çalışmaya alınma tarihlerinden dört hafta öncesine kadar KOAH akut atağı geçirmemiş olmak olarak kabul edilmiștir. Bu tanımlamaya göre hastaların nefes darlığında kötüleșme, çıkardıkları balgamın pürülansında ya da miktarında artış şeklinde belirtilen üc kriterden ikisinin mevcut olması klinik olarak KOAH atağı tanısı koydurmaktadır. KOAH dışında bilinen ek bir akciğer hastalığı olan, son iki ay içerisinde oral kortikosteroid tedavisi kullanmış olan olgular çalışmaya alınmamıştır. Çalışmaya dahil edilen kontrol grubu olguları ise Göğüs Hastalıkları Polikliniğine başvuran ve yapılan tetkiklerinde ve muayenelerinde bir patoloji saptanmamış olgulardan seçilmiștir.

Çalıșmanın başlangııında olguların tümünden bilgilendirilmiş olur formu alınmıştır.

KOAH ve kontrol grubundaki olguların tümüne, Solunum Laboratuarı'nda oturur pozisyonda SFT (spirometre, akciğer volümleri), NEB aleti ile EAK’nın tayini yapılmıştır.

\section{Solunum Fonksiyon Testleri}

Spirometrik incelemeleri Solunum Laboratuarında Sensor Medics Vmax Series 22 kullanılarak yapılmıștır. Zorlu spirometrik trase, bireyin spirometre cihazına total akciğer kapasitesi seviyesine kadar hızlı ve zorlu solutmayı takiben yine hızlı ve zorlu inspire etmesi istenerek elde edilmiștir. Eğri en az üç kez burun kapatılmış durumda iken ağız yoluyla solunum yaparken çizdirilmiş ve elde edilen üç trase içerisinden en büyük FVC ve FEV1 değerleri çalışmamızda kullanılmıştır. Total akciğer volüm ve rezidüel volüm ölçümleri Nitrojen Washout yöntemi kullanılarak yapılmıștır (8).

\section{Negatif Ekspiratuar Basınç (NEB)}

Çalışmamızda EAK'nın tespiti için NEB yöntemi kullanılmıştır. Bu metodun uygulanabilmesi için gerekli aletler șu şekildedir;

Pnömotograf

Diferansiye basınç transdüseri

Negatif basınç olușturan cihaz

Veri toplama sistemi

Plastik bir ağızlık T tüpüne ve pnömotografa bağlıdır. T tüpünün bir ucu atmosfere açıktır. Diğer ucu ise bir kapak (solenoid kapak, Hans Rudolph kapak) yardımıyla venturi apereyi veya vakum jenaratörünün olușturduğu negatif basınca maruz kalmaktadır. Kapak açıldı̆̆ına NEB hava yolu ağzına uygulanmaktadır. Havayolu akımı (V $\square$ ) pnömotograf ile ölçülürken eș zamanlı 
olarak hava yolu açılma basıncı (Pao) ağız parçasının yan portu ile ölçülür. Volüm (V) ise veri toplama sistemlerinde akım sinyallerinin numerik integrasyonundan elde edilir. NEB ile elde edilen A-V halkası, bir önceki normal solunum ile elde edilen A-V halkası ile üstüste çizdirilir. Verilerin analizi iki A-V halkasının görsel değerlendirilmesi ile yapılmaktadır (9). Çalıșmamızda Micro NEP marka bir NEB cihazı kullanılmıștır (Micro Medical Ltd. Kent, UK).

NEB tekniğinden elde edilen sonuçlar üç şekilde yorumlanmaktadır:

*Akım kısıtlılığı yok

* Ekspirasyonun bir kesimi boyunca akım kısıtlı

* Tüm ekspirasyon boyunca akım kısıtlı. Ekspirasyonun akım limitli kesimi, kontrol tidal volümün yüzdesi (VT \%) olarak verilmektedir (9).

Sekil 1'de izlendiği gibi eğer NEB uygulaması kontrol VT'nin tümü boyunca akımda artışa yol açıyorsa, hasta akım kısıtlı değildir (NEB örnek, sol panel). Tersine; NEB ile ekspirasyon sırasında oluşan A-V halkası, kontrol A-V halkasının bir kısmı veya tümü ile kesişiyor ise kiși akım limitlidir (NEB örnek, orta ve sağ panel) (Șekil 1).

Verilerin analizinde SPSS (Statistical Package for Social Sciences, SPSS Inc., Chicago, Illinois, USA) for Windows 10,0 istatistik paket programı kullanılmıștır. Çalıșmamızda örneklem sayısını belirlerken, KOAH olgularında NEB yönteminin incelendiği literatürde yer alan çalıșmalar esas alınmıştır. Çalıșmanın sonunda yapılan post hoc power analizinde FVC için \%95 güven aralığında power \%100 olarak bulunmuștur. Verilerin normallik analizi Kolmogorov Smirnov ile değerlendirilmiștir. Parametrelerin karşılaştııılmasında Mann-Whitney U testi, testi kullanılmıștır. Korelasyon analizlerinde Pearson yöntemi kullanılmıștır. Değerler ortalama \pm standart sapma ve normal
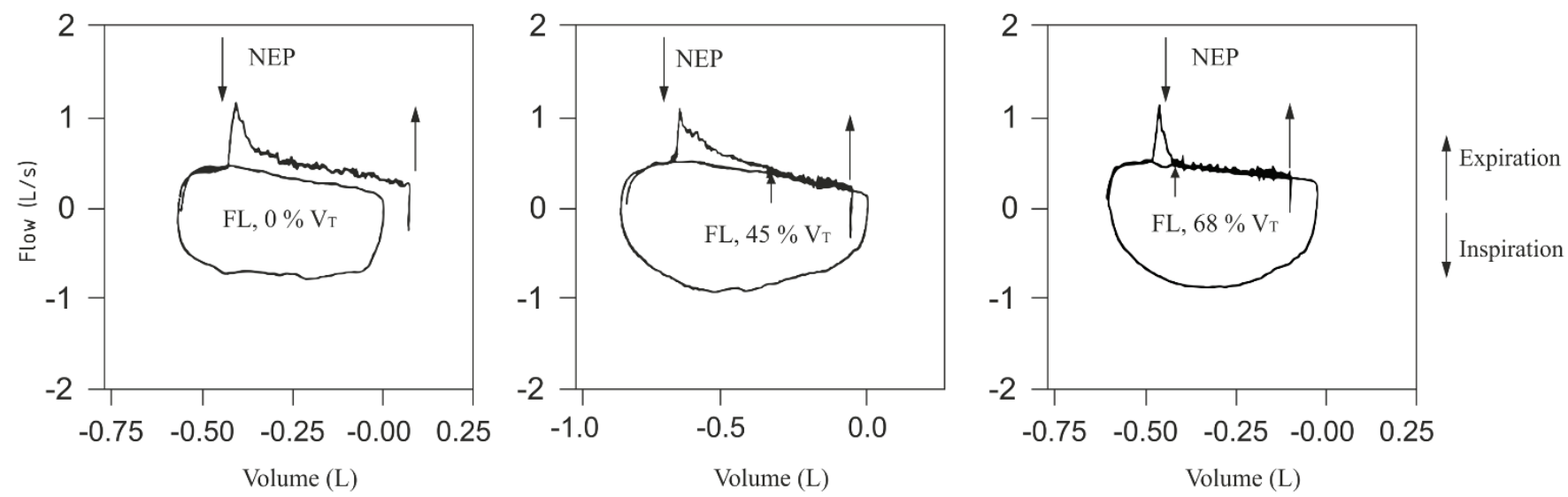

dağılıma uymayanlar medyan ve IQR25-75 olarak verilmiş ve 0,05’den daha küçük p değerleri anlamlı olarak kabul edilmiștir.

\section{BULGULAR}

Olguların demografik özellikleri tablo 1'de gösterilmiștir. Hasta ve kontrol grubunun yaş ortalamaları karşılaștıııldı̆̆ında aralarında istatistiksel açıdan fark saptanmamıştır $(p>0,05)$.

Hasta ve kontrol grubunun spirometrik değerleri tablo 2'de, akciğer volümleri tablo 3'de karşılaştırmalı olarak sunulmaktadır.

Hasta ve kontrol grubunun tüm olgularına NEB tekniği uygulanmıștır. Kontrol grubundaki olgulardan hiçbirinde EAK tespit edilmemiștir. KOAH'lı olgulardan 16 (\%47,1)'sında EAK pozitif saptanmışıtır. Ekspiratuar akım kısıtlaması tidal volümün yüzde değeri olarak ifade edildiğinde ortalama EAK değeri \%31,44 ¿38 șeklinde bulunmuştur.

Çalışma grubu, EAK'sı pozitif ve negatif olanlar olmak üzere iki gruba ayırarak, iki grup arasındaki değişkenler incelenmiștir. Iki grup arasında yaş, içilen sigara miktarı, hastalık süreleri açısından istatistiksel olarak anlamlı fark saptanmamıştır $(p>0,05)$. EAK'sı pozitif olan grup ile negatif olan grubun spirometre değerleri tablo 4'de sunulmuş olup FEV1 (\%) ve FEF \%25-75 (\%) değerleri arasında istatistiksel açıdan anlamlı fark tespit edilmiştir.

Tablo 1. Hasta ve kontrol grubunun demografik özellikleri

\begin{tabular}{|l|l|l|}
\hline & KOAH Grubu & Kontrol Grubu \\
\hline Olgu sayısı (K, E) & $34(2 \mathrm{~K}, 32 \mathrm{E})$ & $15(2 \mathrm{~K}, 13 \mathrm{E}) *$ \\
\hline Yaş (yıl) & $66,3 \pm 7,9$ & $66,7 \pm 7,7 * *$ \\
\hline Hastalık süresi (yıl) & $7,97 \pm 5$ & - \\
\hline Sigara (paket/yıl) & $57,6 \pm 29,7$ & - \\
\hline Sigarayı bırakan olgu sayısı & 31 & - \\
\hline Sigarayı bırakma süresi (yıl) & $4,1 \pm 4,7$ & - \\
\hline * p>0,05, **p $>0,05$ K: Kadın, E: Erkek & & \\
\hline
\end{tabular}

Şekil 1. Akım kısıtlıığı olan ve olmayan olguların NEP örnekleri (5) 
Ekspiratuar akım kısıtlılı̆̆ı olan ve olmayan grubun akciğer volümleri karşılaştırması ise tablo 5 'de gösterilmektedir ve iki grup karşılaştııılı̆ı̆ında istatistiksel olarak anlamlı fark saptanmamıștır.

KOAH'lı grupta ölçülen IC değerinin, yaş, hastalık süresi, ekspiratuar akım kıstlılığı varlığı, solunum fonksiyon testleri ve akciğer volümleri ile korelasyon katsayıları tablo 6'de sunulmuștur. Tabloda da izlendiği gibi IC ile solunum fonksiyon testleri ve akciğer volümleri arasında anlamlı korelasyonlar tespit edilmiștir. Fakat IC ile akım kısıtlaması arasında negatif fakat istatistiksel olarak anlamlı olmayan bir korelasyon tespit edilmiştir.

\begin{tabular}{|c|c|c|}
\hline $\begin{array}{l}\text { SOLUNUM FONKSIYON } \\
\text { TESTLERI }\end{array}$ & HASTA GRUBU & KONTROL GRUBU \\
\hline $\mathrm{FVC}(\mathrm{mL})$ & $2365 \pm 643$ & $3975 \pm 629 *$ \\
\hline FVC $(\%)$ & $72,1(61,1-81,2)$ & $102,3(94,6-110,2) * \mp$ \\
\hline $\mathrm{FEV}_{1}(\mathrm{~mL})$ & $1001 \pm 300$ & $3258 \pm 551 *$ \\
\hline $\mathrm{FEV}_{1}(\%)$ & $38,9 \pm 12,7$ & $104,3 \pm 13,3^{*}$ \\
\hline $\mathrm{FEV}_{1} / \mathrm{FVC}(\%)$ & $42,8 \pm 7,6$ & $79,7 \pm 5,2^{*}$ \\
\hline $\mathrm{FEF}_{\% 25-75}(\mathrm{~L} / \mathrm{sn})$ & $0,25(0,11-0,47)$ & $3,4(2,46-4,8)^{*} t$ \\
\hline $\mathrm{FIV}_{1}(\mathrm{~mL})$ & $1800(1212-2500)$ & $3480(2600-4300)^{*} t$ \\
\hline \multicolumn{3}{|l|}{$* p<0,000$} \\
\hline \multicolumn{3}{|c|}{ Parantez içindeki veriler medyan ve IQR25-75'dir. } \\
\hline \multicolumn{3}{|c|}{ Ғ Mann-Whitney U test kullanılmıștır. } \\
\hline \multicolumn{3}{|c|}{$\begin{array}{l}\text { FVC: Zorlu vital kapasite, FEV: Z Zorlu ekspiratuar kapasite birinci saniye, FEF: Zorlu } \\
\text { ekspiratuar akım, FIV Z Zorlu inspiratuar kapasite birinci saniye }\end{array}$} \\
\hline
\end{tabular}

\begin{tabular}{|c|c|c|}
\hline AKCiĞER VOLÜMLERi & HASTA GRUBU & KONTROL GRUBU \\
\hline $\mathrm{TLC}(\mathrm{mL})$ & $6610 \pm 1896$ & $6157 \pm 776$ \\
\hline TLC (\%) & $109,5 \pm 26,3$ & $97,5 \pm 10^{*}$ \\
\hline $\mathrm{RV}(\mathrm{mL})$ & $3980(2504-4904)$ & $2261(1724-2803)^{* *} \mathrm{t}$ \\
\hline RV (\%) & $169,1 \pm 50,9$ & $102,3 \pm 13,6^{* *}$ \\
\hline RV/TLC (\%) & $59,6 \pm 8,9$ & $35,2 \pm 3,3 * *$ \\
\hline $\mathrm{VC}(\mathrm{mL})$ & $2604 \pm 747$ & $3919 \pm 554 * *$ \\
\hline VC (\%) & $74,4 \pm 21,9$ & $96,8 \pm 10,7^{* *}$ \\
\hline $\mathrm{IC}(\mathrm{mL})$ & $1885 \pm 499$ & $3023 \pm 723 * *$ \\
\hline $\mathrm{FRC}(\mathrm{mL})$ & $4699 \pm 1643$ & $2951 \pm 539 * *$ \\
\hline FRC (\%) & $140,5 \pm 42,6$ & $94,6 \pm 14,8^{* *}$ \\
\hline $\mathrm{ERV}(\mathrm{mL})$ & $705(312-1115)$ & $702(524-1064) €$ \\
\hline \multicolumn{3}{|l|}{${ }^{*} \mathrm{p}<0,05, * * \mathrm{p}<0,000$} \\
\hline \multicolumn{3}{|c|}{ Parantez içindeki veriler medyan ve IQR25-75 dir. } \\
\hline \multicolumn{3}{|c|}{ Ғ Mann-Whitney U test kullanılmıştır. } \\
\hline \multicolumn{3}{|c|}{$\begin{array}{l}\text { TLC: Total akciğer kapasitesi, RV: Rezidüel volüm, VC: Vital kapasite, IC: İnspiratuar } \\
\text { kapasite, FRC: Fonksiyonel rezidüel kapasite, ERV: Ekspiratuar rezerv volüm }\end{array}$} \\
\hline
\end{tabular}

\section{TARTIŞMA}

KOAH'nın patofizyolojik olarak temel noktası ekspiratuar akım kısıtlamasının varlığıdır. EAK'nın en önemli nedeni DH ve artmış solunum iş yüküdür. Solunum yollarında DH'nun varlığını yansıtmada IC'nin en iyi prediktör olduğu özellikle egzersiz intoleransının değerlendirildiği çalıșmalar ile gösterilmiștir. Son yıllarda bronkodilatör tedavinin etkinliğini değerlendirme de FEV1 yerine IC'nin kullanımı önerilmektedir (10, 11). DH'nun en önemli nedeni olan hava akımı kısıtııığını göstermenin en basit yollarından biri de NEB uygulamasıdır.

Çalıșmamızda orta ve ileri derecede KOAH'ı olan 34 olgudan 16 $(\% 47,1)$ tanesinde oturur pozisyonda EAK pozitif, $18(\% 52,9)$ 'inde ise EAK negatif saptanmıştır. Ekspiratuar akım kısıtlaması olan ve olmayan iki KOAH'lı olgunun NEB uygulaması Şekil-2 ve Şekil-3'de gösterilmiștir. Koulouris ve arkadașları ortalama FEV1 değerleri \%60 22 olan 26 ambulatuar KOAH'lı olguya NEB uygulamışlar ve 7 (\%26,9)'sinde EAK negatif bulmuşlardır (12). Eltayara ve arkadaşları 75'i erkek ve 42'si kadın olan toplam 117'i stabil dönemdeki KOAH'lı olguya NEB uygulaması sonucu $26(\% 22,2)$ olguda EAK negatif olarak saptamışlardır (13). Her iki çalıșmada da NEB uygulaması aynı olguya hem oturur hem de yatar pozisyonda yapılımıștır. İki çalıșmada da EAK negatif olarak saptanan olguların hem oturur hem de yatar pozisyonda akım kısıtlaması saptanmamıștır. Bizim çalıșmamızda NEB uygulaması

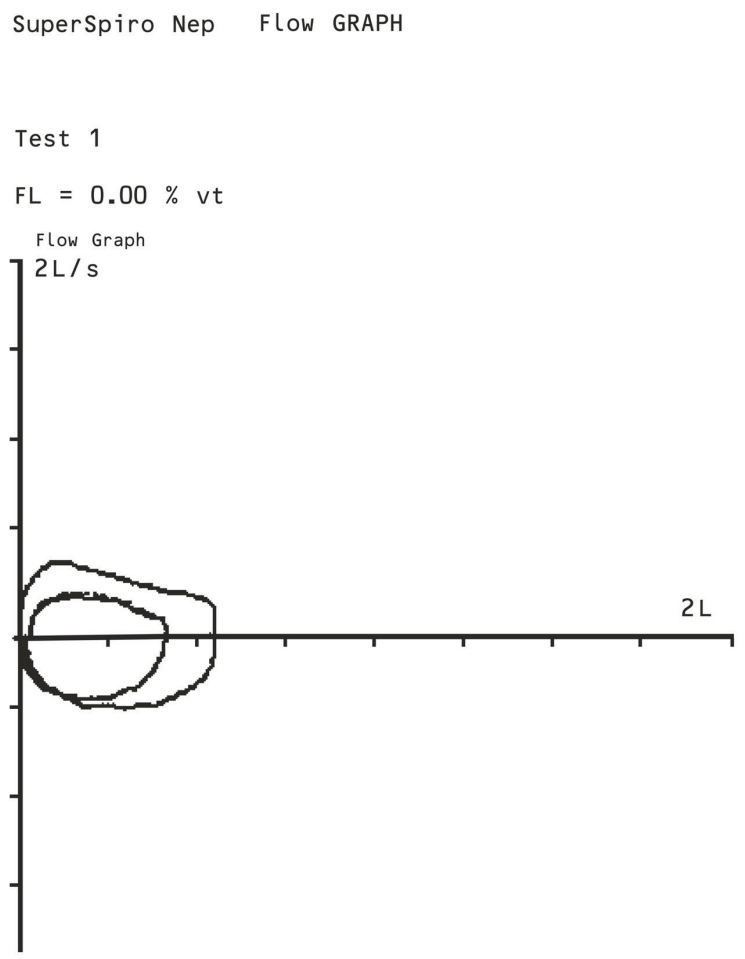

Sekil 2. Ekspiratuar akım kısıtlaması olan KOAH olgusunun NEP uygulaması 


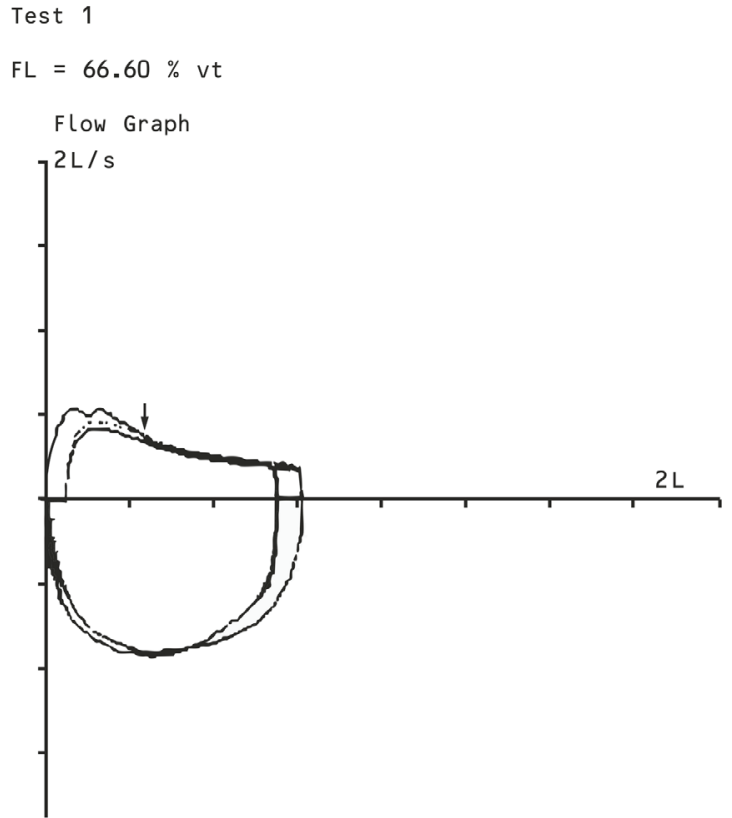

Şekil 3. Ekspiratuar akım kısıtlaması olmayan KOAH olgusunun NEP uygulaması

\begin{tabular}{|c|c|c|}
\hline $\begin{array}{l}\text { SOLUNUM FONKSIYON } \\
\text { TESTLERI }\end{array}$ & EAK NEGATIF & ЕAK POZITIF \\
\hline $\mathrm{FVC}(\mathrm{mL})$ & $2459,4 \pm 623,6$ & $2260,6 \pm 6669,6$ \\
\hline FVC (\%) & $76,7(51,2-98,3)$ & $68,2(49,2-87,3) €$ \\
\hline FEV1 (mL) & $1080 \pm 326,5$ & $913,7 \pm 248,3$ \\
\hline FEV1 (\%) & $43,5 \pm 14,5$ & $33,8 \pm 8^{*}$ \\
\hline FEV1 /FVC (\%) & $44,6 \pm 8,8$ & $40,9 \pm 5,5$ \\
\hline FEF \%25-75 (L/sn) & $0,37(0,22-0,53)$ & $0,29(0,21-0,49 €$ \\
\hline FEF \%25-75 (\%) & $12,8(7,3-16,4)$ & $9,4(6,4-13,4) * t$ \\
\hline \multicolumn{3}{|l|}{$* p<0,05$} \\
\hline \multicolumn{3}{|c|}{ Parantez içindeki veriler medyan ve IQR25-75 dir. } \\
\hline \multicolumn{3}{|c|}{ Ғ Mann- Whitney U test kullanıımıștır. } \\
\hline \multicolumn{3}{|c|}{$\begin{array}{l}\text { FVC: Zorlu vital kapasite, FEV1: Zorlu ekspiratuar kapasite birinci saniye, FEF: } \\
\text { Zorlu ekspiratuar akım }\end{array}$} \\
\hline
\end{tabular}

sadece oturur konumda yapıldığından EAK negatif saptanma oranı literatür ile karșılaștırıldığında daha yüksek bulunmuştur. Literatürde akım kısıtııı̆ı̆ını sadece oturur pozisyonda NEB uygulaması ile tespit eden iki çalıșmada ise çalıșmamızla uyumlu oranlarda akım kısıtlıı̆̆ının pozitif olarak bulunma oranları yüksektir. Diaz ve arkadaşlarının yaptığı çalışmada EAK $\% 55,7$ oranında, Tantucci ve arkadaşlarının incelemesinde ise \%61,1 oranında EAK pozitif saptanmıștır $(14,15)$.

Çalışmamızda EAK'sı pozitif ve negatif olan olguların tüm solunum fonksiyon testleri karșılaștııılı̆̆ında yalnızca FEV1\% predikte ve FEF\%25-75 predikte istatistiksel olarak anlamlı derecede farklı

\begin{tabular}{|c|c|c|}
\hline AKCIĞER VOLÜMLERI & EAK NEGATIF & EAK POZITIF \\
\hline $\mathrm{TLC}(\mathrm{mL})$ & $6920 \pm 1605$ & $6223 \pm 2219 *$ \\
\hline TLC (\%) & $116,3 \pm 20,4$ & $101 \pm 31,1^{*}$ \\
\hline $\mathrm{RV}(\mathrm{mL})$ & $4276(3325-5135)$ & $3620(2704-4226)^{*} \mp$ \\
\hline RV (\%) & $180,3 \pm 39,6$ & $155,1 \pm 61,2^{*}$ \\
\hline RV/TLC (\%) & $62 \pm 6,6$ & $56,5 \pm 10,6^{*}$ \\
\hline $\mathrm{FRC}(\mathrm{mL})$ & $4954 \pm 1385$ & $4382 \pm 1935^{*}$ \\
\hline FRC (\%) & $148,4 \pm 33,4$ & $130,6 \pm 51,7^{*}$ \\
\hline $\mathrm{IC}(\mathrm{mL})$ & $1921 \pm 475$ & $1843 \pm 543^{*}$ \\
\hline \multicolumn{3}{|l|}{${ }^{*} \mathrm{p}>0,05$} \\
\hline \multicolumn{3}{|c|}{ Parantez içindeki veriler medyan ve IQR25-75 dir. } \\
\hline \multicolumn{3}{|c|}{ Ғ Mann-Whitney U test kullanıImıștır. } \\
\hline
\end{tabular}

\begin{tabular}{|c|c|}
\hline PARAMETRELER & KORELASYON KATSAYILARI (r) \\
\hline Yaş (yıl) & 0,242 \\
\hline Hastalık süresi (yıl) & $-0,373$ \\
\hline EAK varlığı & $-0,202$ \\
\hline FVC (\%) & $0,592^{* * *}$ \\
\hline $\mathrm{FEV}_{1}(\%)$ & $0,519 * *$ \\
\hline $\mathrm{FEV}_{1} / \mathrm{FVC}(\%)$ & 0,047 \\
\hline PEF (\%) & $0,666^{* * *}$ \\
\hline TLC (\%) & $0,573^{* *}$ \\
\hline $\mathrm{VC}(\mathrm{mL})$ & $0,797 * * *$ \\
\hline VC (\%) & $0,599 * * *$ \\
\hline FRC $(\mathrm{mL})$ & $0,438^{*}$ \\
\hline $\mathrm{RV}(\mathrm{mL})$ & 0,484 * \\
\hline $\mathrm{RV}(\%)$ & $0,429 *$ \\
\hline
\end{tabular}

bulunmuştur $(p<0,05)$. Literatürdeki çalıșmalarda da EAK'sı pozitif olan KOAH'lı olgularda FEV1 \%predikte değerinin anlamlı derecede düșük olduğu gösterilmiștir $(13,16)$.

NEB yöntemi ile EAK varlığı incelenerek dinamik hiperinflasyon hakkında bilgi sahibi olunabilmektedir. Bu konu ile ilgili yapılmış çalışmaların çoğunda KOAH'ı olgularda EAK'nın varlığı artmış akciğer volümleri arasında anlamlı bir ilişki saptanmıştır. Koulouris ve arkadașları \%TLC, \%RV, RV/TLC, \%FRC değerleri arasında anlamlı fark saptarken, Diaz ve arkadașları TLC\% hariç diğer parametrelerde istatistiksel olarak anlamlı fark saptamıșlardır $(16,17)$. Boni ve arkadașları ise bizim çalışmamızda olduğu gibi akım limitasyonu olan ve olmayan gruplar arasında akciğer volümleri açısından anlamlı fark tespit etmemişlerdir $(14,18)$. 
Son yıllarda yapılan çalıșmalarda; KOAH'lı olgularda farmakolojik ve cerrahi tedavinin etkinliğini değerlendirmede, egzersiz sırasında gelișen fizyolojik değișiklikleri tanımlamada ve KOAH'da en önemli semptom olan dispne ile korele, yeni bir parametre olan IC'nin önemi vurgulanmaktadır (3). Çalıșmamızda DH'nun değerlendirilmesinde IC'nin diğer akciğer volümleri, NEB olan ilișkileri incelenmiștir. IC ile hava yolu obstrüksiyonunun göstergeleri olan \% FVC predikte, \% FEV1 predikte, \% PEF predikte, değerleri arasında istatistiksel olarak kuvvetli bir korelasyon saptanmıştır ( $p>0,05)$. Diazve arkadașları, Tantucci ve arkadaşları ile Koulouris ve arkadaşlarının yaptığı çalıșmalarda IC ile akım kısıtlamasının varlığı arasında negatif istatistiksel olarak anlamlı korelasyon saptamıșlardır, bizim çalıșmamızda da negatif fakat istatistiksel olarak anlamlı olmayan bir korelasyon bulunmuștur. KOAH olgularında ekspiratuar akım kısıtlılığı ile IC arasında ki ilișkinin varlığı dinamik hiperinflasyonun tespitinde NEB yönteminin önemini göstermektedir. Dinamik hiperinflasyonun tespitinde ucuz, pratik ve uygulanması kolay bir yöntem olan NEB yönteminin KOAH olgularında daha yaygın kullanımını ortaya koymaktadır. Çalıșmamızda TLC, FRC, VC ve RV değerlerinin hem $\mathrm{ml}$ hem de \%predikte değerleri ile IC arasında Diaz ve arkadașlarının çalıșmasında olduğu gibi korelasyon saptanmıștır $(14,16,17)$.

\section{SONUC}

Sonuç olarak; çalışmamızda KOAH'lı olgularda, ekspiratuar akım kısıtılığının NEB yöntemi ile bakılmasının dinamik hiperinflasyon hakkında ek bilgi sağlamadığını gösterdik. Basit olarak bakılabilen inspiratuar kapasitenin, dinamik hiperinflasyonun en iyi prediktörü olduğunu söyleyebiliriz.

\section{KAYNAKLAR}

1. Global Initiative For Chronic Obstructive Lung Disease. Global Strategy For The Diagnosis, Management, And Prevention Of Chronic Obstructive Pulmonary Disease NHLBI/WHO Workshop Report. U.S. Department of Health and Human Services. Public Health service. National Institutes of Health. National Heart, Lung, and Blood Institute. NIH Publication No. 2701 April 2001.

2. Corne $S$, Anthonisen NR. Lung-function testing in chronic obstructive pulmonary disease. In: Voelkel NF, MacNee W (eds) Chronic obstructive lung disease. Hamilton, BC Decker Inc. 2002:257-269.
3. O'Donnell DE, Lam M, Webb KA. Measurement of symptoms, lung hyperinflation and endurance during exercise in chronic obstructive pulmonary disease. Am J Respir Crit Care Med 1998;158:1557-1565.

4. O'Donnell DE, Lam M, Webb KA. Measurement of symptoms, lung hyperinflation and endurance during exercise in chronic obstructive pulmonary disease. Am J Respir Crit Care Med 1997;155

5. Milic-Emil J. Expiratory flow limitation. Chest 2000;117:2195-2235:19841990.

6. Baydur A, Milic-Emili J. Expiratory flow limitation during spontaneous breathing: comparison of patients with restrictive and obstructive respiratory disorders. Chest 1997;112:1017-1023.

7. Murariu C, Ghezzo H, Milic-Emili J, Gautier H. Exercise limitation in obstructive lung disease. Chest 1998;114:965-968.

8. American Thoracic Society: Standardization of spirometry-1994 update. Am J Respir Crit Care Med 1995;152:1107-1136.

9. Koulouris NG. Negative expiratory pressure: a new tool. Monaldi Arch Chest Dis 2002; 57:1, 69-75.

10. O'Donnell DE, Revill SM, A Webb K. Dynamic hyperinflation and exercise intolerance in chronic obstructive pulmonary disease. Am J Respir Crit Care Med 2001;164:770-777.

11. O'Donnell DE. Assessment of bronchodilator efficacy in symptomatic COPD: is spirometry useful? Chest 2000; 117 (2 Suppl):42-47.

12. Koulouris NG, Dimopoulou I, Valta P. Detection of expiratory flow limitation during exercise in COPD patients. J Appl Physiol 1997;82(3):723-731.

13. Eltayara L, Becklake MR, Volta CA, Milic-Emili J. Relationship between choronic dyspnea and expiratory flow limitation in patients with choronic obstructive pulmonary disease. Am J Respir Crit Care Med 1996;154:17261734.

14. Tantucci C, Duguet A, Similowski T. Effect of salbutamol on dynamic hyperinflation in choronic obstructive pulmonary disease patients. Eur Respir J 1998; 12:799-804.

15. Diaz 0, Villafranca C, Ghezzo H,. Role of inspiratory capacity on exercise tolerance in COPD patients with and without tidal expiratory flow limitation at rest. Eur Respir J 2000;16:269-275.

16. Koulouris NG, Valta P, Lavoie A. A simple method to detect expiratory flow limitation during spontaneous breathing. Eur Respir J 1995;8:306-313.

17. Diaz O, Villafranca C, Ghezzo H,. Role of inspiratory capacity on exercise tolerance in COPD patients with and without tidal expiratory flow limitation at rest. Eur Respir J 2000;16:269-275.

18. Boni E, Corda L, Franchini D. Volume effect and exertional dyspnea after bronchodilator in patients with COPD with and without expiratory flow limitation at rest. Thorax 2002;57:528-532. 